\title{
TREADING UNKNOWN WATERS: THE ADOLESCENT FATHERS' CHALLENGES AND HOW THEY HAVE COPED WITH THESE CHALLENGES
}

Dyan T. Gapulan

\begin{tabular}{l}
\hline Paper Received: 02.05.2020 / Paper Accepted: 08.06.2020 / Paper Published: 17.06.2020 \\
\hline Corresponding Author: Dyan T. Gapulan; Email: dyan76ers@yahoo.com; doi:10.46360/globus.xxxxxxxx \\
\hline
\end{tabular}

\begin{abstract}
The adolescent males are partners to the phenomenon of adolescent pregnancy, yet there is no current intervention found to address their concerns. In this research, qualitative research design was used to understand the challenges experienced by the adolescent fathers and the ways they have coped with these challenges. No current data shows the population of the adolescent fathers, yet some pregnant adolescents identified some partners who are also adolescents themselves. The researcher started from two (2) participants who are enrolled in the state college, utilizing purposive sampling at this stage and the participants identified more enrolled adolescent fathers, which started the snowball sampling, thus coming up to the eight participants. The researcher made use of an unstructured interview guide to identify the challenges experienced by the adolescent fathers and the coping they have employed to overcome these challenges. From their responses, two main themes were identified for their challenges, which are: societal and personal challenges. The societal challenges include: family affairs, girlfriends (now life partners) and their fears of judgment. Their personal challenges include: financial and baby worries, the need for "me" time and student blues. Their coping manifest two themes: avoidant/emotion-focused coping and proactive/problem-focused coping, which include: budgeting, appease and communicate and acceptance. The results of this research will be made a basis for implementing a program for the deterrence of adolescence pregnancy and fatherhood.
\end{abstract}

Keywords: Challenges, Adolescent Pregnancy, Coping.

\section{Background of the Study}

The prevalence of adolescent pregnancy continues to become a global concern to this day. The World Health Organization (2012) states that the incidence of adolescent pregnancy from developing countries comprises one-third of women who give birth (Parungao, C., Bautista, L., Mariano, R., Bonifacio, V. and Aguinaldo, M., 2014).

Parenthood during adolescence can be viewed as an abrupt change in developmental roles, since adolescents are forced to accept roles for which they are not developmentally prepared for. In the child welfare arena, the adolescent parents are known as "jigsaw puzzle children" because of the fragmented nature of their personality and development (Bernal, 2013). The role of parenthood during the period of adolescence is not included as part of the developmental tasks of adolescence according to Havighurst (1972).

Studies suggest that adolescent females have the tendency to engage in a relationship with adolescent males. Teen moms engage in intercourse with teen boys who are close in their age (Senn and Carey, 2011). This finding was further affirmed by Molborn and Lovegrove (2011) who claimed that $30 \%$ to $50 \%$ of children born to adolescent mothers also have adolescent fathers.

In the local state college in Negros Occidental, records reveal that out of 15 adolescent pregnancy cases recorded in the academic year 2015-2016, 11 in the cases also involved adolescent fathers. As a partner to the pregnancy, the adolescent fathers are important collaborators whose experiences are worthy to be investigated. Despite their important involvement into the phenomena of adolescent pregnancy, however, little research has been given to the important roles of the adolescent fathers (Lee, Sansone, Swanson and Tantum, 2012). Much of the interventions are targeted towards the mothers, but the adolescent fathers are left on the sidelines. Since they do not bear the weight of childbearing, so little is known about their experiences; they are overlooked, excluded and forgotten (Paschal, et al., 2011). Answers to these questions regarding the experiences of the adolescent fathers are very important to be sought: What were the circumstances which have influenced them? What are the challenges which they are experiencing as 
adolescent fathers? What are their needs? These, among others, need answers in order to truly understand adolescent pregnancy, especially the adolescent fathers' side of the story.

\section{Theoretical Background and Related Studies}

The Psychosocial theory of Erik H. Erikson provides a strong theoretical framework for this study. Erikson claimed that the fifth psychosocial crisis, coinciding with the developmental stage of adolescence, is the stage of Identity vs. Role Confusion (Corpuz et. al., 2010). Erikson affirmed that in this fifth stage, the adolescent inquires, "Who am I?" The adolescent explores himself, his roles, and his own "niche under the sun." When he achieves an understanding of his roles, he achieves a sense of identity; he acquires a sense of individuality. When this kind of understanding is not achieved, the individual may experience role confusion. Rice (2010) states that if one successfully negotiates this stage, he will develop a strong sense of self. Fatherhood during the stage of adolescence may not be an appropriate role to engage in, but understanding himself during this stage may set the stage for self-understanding and successfully negotiating his role in the society.

In addition, the theory of Urie Bronfenbrenner, the Bioecological model theory proposed that the person's development occurs within the context of a complex set of relationship system (Corpuz et. al., 2010). Urie Bronfenbrenner claimed that the person is influenced by different layers of influence which continue to impact the individual. The person's interpersonal relationship, even at the most basic level, has occurred due to the complex interaction between the individual and his environment (Lucas and Corpuz, 2013). In understanding the person, therefore, it is essential that all layers of possible influence should be considered. The different layers of influence include the microsystem, the macrosystem and the exosystem (Corpuz et. al., 2010). An adolescent father, thus, is an outcome of the dynamic interaction of the individual and his environment.

Research literatures regarding adolescent fathers, though scarce, relate the circumstances surrounding the experiences of the teen fathers. Science suggests that the reasoning and decision-making of adolescents are influenced by the still developing frontal lobes of the brain, which becomes fully mature by the time they reach 26. This physiological fact suggests that it is not surprising why at-risk males tend to view women as anything other than a sexual object (Mc Bride, 2013).

Several circumstances place the male adolescents to become at-risk for becoming fathers at an early age. Delinquency, substance abuse, parental education and early sexual initiation are conditions which may set the stage for teen fatherhood (Sipsma, 2011). In a similar study conducted by Shade, et. al. (2011), it has been found that poverty, school failure, alcohol and/or drug use, gang involvement, early sexual activity and lack of male role models are common risk factors for adolescent fatherhood. In fact, the National Fatherhood Initiative (2010) claimed that it has been found that incarcerated teen fathers constitute $30 \%$ of the total juvenile incarcerated population.

Several studies show that some factors play a protective role on the males for adolescent fatherhood. Weinman et. al. (2008) said parental communication, peer influence, positive attitudes towards condoms and self-efficacy had significant positive impact on the male adolescents. These conditions, when present, may form a protective layer and keep them from experiencing early fatherhood.

As a result of early fatherhood, these adolescent males are more likely to turn to delinquent behaviour, experience high aggression, have low socioeconomic status, and acquire limited educational attainment and fewer employment opportunities than their non-parenting peers (Lemay, 2010; Sipsma et. al., 2010). Adolescent fatherhood limits the opportunities available for them, given the absence of social support. Teen fatherhood requires long-term financial resources and commitment which in turn reduces the young man's ability to invest in their own human capital (Hoffeth and Goldscheider, 2010), specifically in their education and skills.

\section{Statement of the Problem}

This research will discover the lived experiences of the adolescent fathers who were partners, either married, unmarried, together or separated, of the recorded pregnant adolescents during the Academic Year 2015-2016. Specifically, this research will answer:

1. What are the challenges experienced by the adolescent fathers?

2. How did they cope with these challenges?

\section{Methodology}

In this research, the qualitative research design was used specifically the phenomenological approach to research. This research will probe in-depth into the experiences of the adolescent fathers by looking into their past, present and future as teen fathers.

Nonprobability sampling method will be utilized in identifying the participants for this research. The Guidance Counselor will provide referrals to enrolled adolescent fathers, who have become fathers within the academic year 2016-2017. The 
participants should be the ages within 16-20 years old.

The participants beyond 18 years old have signed a consent form signifying their assent to participate. For the participants below 18 years of age, one of the parents or guardian signed the consent form signifying that they allow their sons to be interviewed.

In gathering information, the researcher designed a semi-structured interview guide to probe for details regarding the lived experiences of the adolescent fathers. Three (3) overarching questions were asked in conformance to the specific objectives, and probing questions were utilized after each overarching question to further investigate the lived experiences of the adolescent fathers.

After each interview, the transcriptions were be made by the researcher, and other observed behaviors were recorded. The data were analyzed through the basic qualitative steps proposed by Creswell (2009). The verbatim transcriptions shall be highlighted and will be made to undergo categorization. The significant portions of the research were categorized into themes. The following basic steps of Creswell in utilizing qualitative data are the following: a. Data collection, b. Data preparation: prepare data for analysis, transcribe verbatim, c. Open coding: identity meaningful segments from the material, d. Axial coding (analytical coding): analyze and group segments into categories, e. Repeat the above process, obtain more categories from more data sets and f. Simultaneously combine categories into themes. The results of the research became a basis for an intervention program to be implemented by the Guidance Office to properly guide not only the adolescent males but the entire student populace in the prevention of early pregnancy.

\section{Results and Discussion}

\section{Challenges Experienced by the} Adolescent Fathers

The challenges experienced by the adolescent fathers, gleaned from their responses in the indepth interview, could be categorized into two: societal and individualistic challenges. Societal challenges are those which involve the challenges they have experienced, concerning their interaction with other people around them. This category of challenges involve: their family affairs, their girlfriends (now their life partners) and their fears of judgment of other people.

The individualistic challenges, on the other hand, involve challenges and problems they have experienced which may not necessarily involve other people, but that which they should confront alone: financial, the need for "me time," baby worries, and their "student blues."

When asked regarding their challenges, it is noted the intense reactions of the adolescent fathers, as they usually start their answers with a sigh, a smile, a pause, reflecting a strong reaction. Their answers usually start with, "damo maam e," (too many, ma'am), according to Bogie, Leovy and Nonoy, "budlay maam e" (it's difficult, ma'am), said Toby and according to Bibo, "tanan-tanan. Tanan-tanan naagyan ko," (Everything. I went through everything).

The societal challenges the adolescent fathers have experienced are the following:

\section{Family Affairs}

The concerns of the adolescent fathers regarding their family affairs are divided into: their concern over their family's reactions and their concerns regarding their partners' families.

Their own family members are sources of distress for the adolescent father. Bogie related that, "ara bala kis-a maam nga gina basol ka sang pamilya mo nga nangasawa ka temprano. Nahambal nila nga ako tani ang nasaligan nga mabulig sa ila maam. Nga amo pa na ginhimo ko. Nahambalan ko ni mama maam. Talikod lang ko e pero gatulo luha ko. Naghinulsol man ko e pero ang paghinulsol ara gid sa ulihi. Wala na ko maam may mahimo. "(Sometimes I am blamed by my family for having a wife at an early age. They tell me that I was expected to help in the family, but this happened. My mother tells me that, and I turn around, but I cry for it. I regret for my decisions but regret comes in the end.) Bibo also said, "akig ni papa kag ni mama. Nga amo na e wala ka pa katapos college nakapabusong ka na. Tapos wala ka pa gapangita kwarta. " (The anger of mama and papa, since I have not graduated from college yet, I do not earn, but I have made a girl pregnant). Leovy recounted how her father was angered once, "Kay nag away man kami to ni papang. Daw nagsabat ko sa iya bala maam haw. Pero sang amo na nga time abi mo tsakto ka pero gahinulsol ka man maam nga amo na, sala na. Amo to maam $3^{\text {rd }}$ year pa lang ko, tapos na ko OJT maam, te nagdesisyon sya maam nga indi nya na ko pag paeskwelahon $4^{\text {th }}$ year. Te galalain ko maam mong. Daw nag... wala ko kabalo kung ano himuon ko syempre ara pa lang ko das a balay. (Papang and I had a heated exchange. I answered back to him, for I was angered by her words and I could not control my temper. During that time I thought I was correct, but later on I regretted what I've done. I was in $3^{\text {rd }}$ year (college) then, and he decided not to enroll me in $4^{\text {th }}$ year (college). I did not know what to do, I was only at home, not doing anything.) He added that his father's anger was due 
to, "kay amo na maam e, nga nakapa busong ko kuno temprano. Ang sang una daw ginbalik nya bala maam haw. Ginliwat nya ang ginpanghambal nya sang una, daw ginbasol nya ko bala haw kay syempre may duha pa ko ka manghod nga babae." (Because I have made a girl pregnant at an early age. He remembered his past anger, and repeated what he said during those times (when he discovered I have made a girl pregnant). He blamed for for I still have two younger sisters.)

Their partners' family members are also sources of problems for the adolescent fathers. Leovy said, "sa pamilya man bala maam haw, syempre daw nahuya ko magsulod sa ila, kay wala ko ubra. Wala man nga ginapa gwa ko nila, sa akon lang pamensaron. Nga daw nahuya ko kay, daw indi ko ka giho sang eksakto. Kay daw nabudlayan ko da bala mag giho sa ila maam haw. "(I am embarassed when I go to her home, since I do not yet have a job. They do not order me to get out, but my mind says it. I find it difficult to move around wit them around.) Bibo also said, "pirme lang kami ga away sang mama nya kag ako maam e. iya pamilya. Kay indi sila magpasugot nga mag upod kami. "(her mama and I always quarrel, and her whole family since they do not want us to be together). JJ further said, "pakitungo bala sang family nya miss haw kay indi boto ang family nya sa akon mong. Kung mag settle down kami kung paano ko makitungo sa pamilya nya nga mag okay kami." (How her family deals with me since her family does not like me. If we settle down, how do I deal with her family so that we could be okay).

Other family members further complicate the experience of the adolescent father. Leovy related of the quarrel of her sister and her partner, "kay sala man sang akon magulang bala maam haw. Daw nagsulod sya bala sa amon relasyon haw. Naghambal sya nga daw indi kuno kabantay sang amon bata ang akon miga. Te nabatian sang miga ko, te daw naglaot sya bala maam haw. Syempre sa amo na nga sitwasyon indi sya kabantay kay halos tanan nga oras ara sya sa bata maam mong. Te daw sala gid sang magulang ko maam e naglain buot ko sa iya." (it was my sister's fault, she intervened in our own affairs. She said my girlfriend could not look after my child. My girlfriend heard about it, and she was angered. How could she not attend to our child when it's what she does the whole time. I knew It was my sister's fault and I was mad at her).

Bogie also said, "kis-a maam ga inaway kami sa balay maam, ako kag ang mga utod ko. Pati na maam sa ubra sa panimalay e. kay ako, estudyante sa adlaw, pagka gab-i tulog na lang ko na. Te sa balay maam may obligasyon man ko mong indi ko na mahimo. Na isipan ko nila maam. Amo na maam ginahambalan ko nila nabaton ko nalang maam e kay sala ko man dyapon. pero nahambalan na sya nila ni mama kag ni papa... pero indi gid malikawan." (sometimes I and my siblings quarrel, regarding household chores. I could not do my obligations, and they do not like it. Since I am a student, I am tired at the end of the day. They tell me and I accept my fault. Mama and papa talks to them about it, but it could not be avoided).

The adolescent fathers, given the socially complicated situations they are in, are more prone to social exclusion (Lehti, et. al., 2012), even within the dynamics of their own family systems. Adolescent fatherhood brings with it the intricate interaction of social, financial, emotional and a host of other problems.

\section{Girlfriend (now life partner)}

Both the adolescent father and the adolescent mother face adjustment problems not only with their new responsibilities but also with their new level of relationship. Nonoy said, "away-away maam e. sa bae bala maam haw. Mga labay labay maam, ga selos sya bala maam haw. Ga selos sya kung may makita sya nga bae nga upod ko, pero friend ko man lang. Mangakig na sya kay selosa nga daan.” (We quarrel regarding other girls. She's jealous when she sees me with other girls, though they are just my friends).

Bibo relates that they experience problems in their relationship, the source of which is their financial problem, as he narrated," inaway kami sa kwarta nga 2 maam e. kami sang partner ko. Kay kis-a kulang gid maam e. indi man gid siling nga tsakto gid indi man siling nga kulang gid.kwarta. Sa mga kinanglanon. (We quarrel over money. Sometimes it is not just enough for our needs). He said his partner tells him, "nga gahinulsol sya nga ako napamana nya." (She regrets that it was me who she chose).

\section{Fears of Judgment}

Other people's opinion at times could become a matter of concern for the adolescent father. Jimmy narrated, "nahuya ko sa mga tao. Nga naka pabusong ko... kay wala ko ubra. Wala ko may isagod. "(I was embarassed, since I became a father early... I do not have a job, I could not support (my family). JJ affirmed this adolescent father's concern as he said, "ang na-worry ko man miss, ang ihambal sang iban bala nga tao nga bata pa kami... gadali gid mangasawa, amo na. Waay anay gin una ang kaugalingon mo nga, ang imo kinitaan indi anay magkadto sa imo, ato na sa bata mo indi ka na kapagusto kay may bata ka na mong." (My only worry is what other people would say, that we were still too young, and we were in a rush to have a family. That we did not prioritize ourselves, that 
we could not enjoy our income for we already have a child).

Toby's concern is primarily the teasing of his instructors, as he narrated, "ara bala nga na discriminate ka maam. Kulbaan ka basi mabal-an. Kay samtang ga eskwela ko di maam indi lang estudyante and nakabalo pati maestro. Iban daan nga maestro indi man kaintyende patay lang sunlog nga sunlog. Napamensar lang nila self interest lang nga mapalipay nila iban nga estudyante wala sila gapamensar nga ano ang epekto sa estudyante nga nasunlog nila. Ang napamensar ko, ano ayhan kung mabal-an sang taga didto sa amon? Ano ayhan gwa sang bata kung ako maka-untat eskwela? Kay kung mabal-an nga daan sang pinaka magulang namon untat dayon eskwela. " (They discriminate you, I was afraid it would be known (by my family). All my teachers knew. Some teachers do not understand and they tease me. They only think of their own self-interest but they do not think of its implications to the student they tease. I worry that the news could reach those in our place. What would happen to my child if I would be forced to stop in my education? If my eldest brother would know, I would immediately be made to stop going to school).

The adolescent fathers' transition to fatherhood could be experienced as stressful (Chin, et. al., 2011)). The adolescent father is faced with many responsibilities and many unfulfilled social expectations. The new role involves a redefinition of the adolescent father's self, including identifying with the parenthood role and anticipating a new level of relationship with the partner (Chin, et. al, 2011). This new level of expectation on the relationship is exerting a new challenge to the already existing number of challenges experienced by the adolescent.

The individualistic challenges experienced by the participants, or those which do not concern his interaction with others, are the following:

\section{Financial}

The challenges posed by the financial concern are almost interwoven into any other fragment of the challenges faced by the adolescent father. Financial concern is a part of his relationship with his family, with his partner, his worries over his baby, his need for personal things, and even his concern over education. For the purpose of this research, however, the financial concern as a whole will be made as a separate challenge as it is related by the adolescent father.

Bibo summed up the financial concerns in his statement, "Kapigaduhon kag ano maam e... kis-a maykwarta kis-a wala man. sa amon pangabuhi maam e. ako nga daan wala ubra. Sya wala man ubra. Kay ga lumon lang kami maam mong. Sa amon balay. (Poverty, for sometimes we have money sometimes none at all. I do not have a job, same as she is. We are dependent on my family). When asked what is this need of money for, he replied, "sa mga kabataan namon maam e. sa pagkaon, sa iya diaper kag gatas. Kinanglanon namon nga duha maam e." (for our children, for her food, diaper and milk, and for our own needs also). Bogie also said, "financial sa pageskwela pagkaon maam. Syempre wala kami ubra mong. Gasalig lang kami sa amon ginikanan. Mga needs namon maam." (financial (need) for our education. We do not have a job and we are dependent on our parents for our needs). JJ said, "nanumdom ko e, for example kung mag upod kami nga duha, paano ko na suportahan ang bata ko kay syempre wala ko katapos. Financial gid, paano ko sya suportahan. Syempre halin pa sa pagkabata, una gid ang gatas. Tapos kung wala ta man napangayo, magmasakit, dal-on sa ospital, wala gid ko sang kwarta. Tapos kung mag settle down kami nga duha, ang kaunon pa namon. Indi man ko kakita sang tsakto nga ubra kay wala man ko katapos, sya wala man." (I was thinking that if we would be together, how could I support my child since I have not finished college? Financial indeed, of how I could support her. Foremost is the milk, and God forbid, if the baby would be ill, and when brought to the hospital, I do not have money for it. If we both settle down, we have to eat. I could not be landed in high-paying jobs for I have not finished college.)

Ken said, "financial problem gid e. kag sa pageskwela ko. Kay sa financial problem maapektuhan man ang pag-eskwela ko. Kay si papa kag ang iya papa man wala man ubra. Husto man lang sa ila kinahanglanon. Amo na maapektuhan man ang pag eskwela ko.sa amo na e plete pa eskwelahan." (Financial problem for my education. Our fathers do not have jobs, and what they have are also adequate for their needs. My education would be affected, especially in my fare going to-and-from school.)

Toby expressed great concern as he said, "Budlay maam e. syempre ga eskwela ka ga tunga ang imo kaugalingon. Ga tunga ang imo allowance. (It's difficult. When you are in school you are troubled, and your allowance is also divided.) When asked regarding why he is troubled when in school, he said, "syempre maam samtang ari ka di sa eskwelahan ang pamensar mo ato to maam. Gapamensar ka, "ano ni ang ibakal ko? Ibakal sang mga kinahanglanon. Budlay maam e." (While I am in school I am thinking of my child. I think about, "What would I use to buy her needs? It's so difficult). 
Leovy on his part said, "estudyante ka pa, indi ka kahatag sa bata mo sang mga kinanglanon nya." (You are still a student and you could not provide your child her needs). Nonoy said, "Financial maam. Kay ano daan maam grabe bala iya masakit maam haw te gin admit sya namon sa Bacolod sa Doctors' (Hospital). Dalagku amon bill maam. Pneumonia. (Financial maam, for once he was admitted in the hospital for he had pneumonia. Our bill soared). He also added that this financial problem could also be related to "pag eskwela pa gid bala maam haw, kung kis-a wala balon." (For my education maam, sometimes I do not have a school allowance).

Jimmy said, "Money. Para sa bata. Gusto ko ibakal maam, gusto ko ihatag tanan. Pagkaon, mga bayo nya. Pero para sa akon, nahuya na ko sa mga parents ko kay daw ginhatag man nila tanan. Dason nahuya na gid ko ya e. Kay lalaki ko mong. Tani ako na ma provide e." (Money for the needs of my child. I am embarassed for my parents have given us everything. I am embarassed since I am the man, I should have been the one to provide for my family).

\section{Baby and Financial Worries}

Their babies and their experiences with the babies are sources of concern for the adolescent father. Leovy narrated, "mag ano na man maam e, sa pulawanay bala maam haw, syempre budlayan ka gid da maam. Once nga ang bata maghibi, tagaan mo gid time para maghipos. Pero bisan ano ka katuyo, controllon mo gid kaugalingon mo magbugtaw para mag kungkong sa bata. Syempre kung gab-i na, ako mismo ga bugtaw kay ginapapahuway ko ang miga ko. Kay syempre bilog nga adlaw sya gabantay, te ako naman kung gab-i maam. Sa akon ok lang magpulaw basta kapahuway lang sya." (Inadequate sleep, I find it a difficulty. When my baby cries, I have to take time to soothe him. During the night I am the one who takes care of the baby. For me it's okay to have inadequate sleep as long as she could take a rest for she is the one who takes care of him the whole day). Nonoy expressed her concern regarding her child's illness, "pagmasakit to bala maam haw sang baby namon. nasubuan maam e kay nakita ko sya nga ga suffer sa iya masakit." (When he got ill, I became sad everytime I see him suffering in his illness).

Toby's concern also involve the financial concerns as he said, "ang bata halin sang gamay pa asta mga 9 months, ka sensitive pa gid. Gamay lang nga masakit, malibog ulo mo diin ka ma kwa maam." (The baby is so sensitive since birth until nine months. During his illness, I become too concerned where to look for [finances].)
The financial instability is apparent in the experiences of these adolescents who have become fathers early. In a study conducted by Hecker-Luz et al., (2010) in Brazil, the employment status of adolescent fathers manifest a lack of formal employment contract, manifesting financial instability. This economic instability is reflected and deeply ingrained in the challenges experienced by the participants. Without the economic autonomy to feed the family and support their own education, the financial incapability is sustained, thus making impossible to realize life plans generating instabilities in their conjugal relationship (Hecker-Luz, et. al., 2010).

\section{Need for "me" Time}

Despite the growing awareness of other people's needs, the adolescent father recognizes that he has his own needs that he feels is also one of the problems he experiences, as he believes these are now deficient in his life.

A lack of time with others, like friends and classmates, is one challenge that the adolescent father experiences. Nonoy said, "Galain man buot ko nga daw indi sya bala gusto nga mag upod ko sa mga friends ko haw. Daw biskan wala kami ga ano." (It saddens me that she does not want me to go with my friends, though we do not do anything wrong). Toby said, "limitado ang giho mo maam e, example bi bonding. For example bi sa college night, syempre indi ka na kabonding kay syempre ang giho mo laban na sa ila kaysa sa mga boardmates mo. Imbes nga ibonding mo sa gab-i indi nalang mapuli nalang to kag uliton nalang ang bata. Buligan ko nalang sya maam." (Limited in terms of my time with friends. For example, during college night, I could not go with my friends since my time should be more with my family than with them. Instead of going out with my friends I just go home to help her look after our child). Bogie also added that one of his needs is, "ano pa gid maam, sa mga needs mo, sa mga gusto mo bala maam haw. Nga maka soltero ka anay nga himuon mo. For example gusto mo mag lagaw lagaw indi ka ka lagaw lagaw kay ifocus mo nalang. Kay subong ang imo panimuot subong iya na gid ya ka tatay indi na iya ka binata. (My needs, with what I want to do like a bachelor. For example I want to go somewhere but I couldn't because I have to focus (on my family). Right now, my perceptions should that of a family man and not that of a bachelor). He also added, "ano maam e, bilang isa ka soltero tani gusto ko man tani maka lagaw lagaw sa iban nga lugar. Te subong nga may pangabuhi na ko dira na gid lang ko tambay sa balay. Bantay sa akon bata. Gusto ko man tani. Indi na ko galing pwede ka lagaw lagaw kay ang bata ko nabantayan ko man. " ( As a bachelor I should have wanted to go places, but since I am now a family man I have to stay at 
home and look after my child). Ken also said, "Kag ang oras. Kay bilang teenage ma-ano ka pa, malagaw-lagaw. Te kay may bata ka na indi ka na ka gwa. Maka-gwa man pero siling nga indi na pareho sang una. Sang wala ka pa bata pagusto ka bisan diin ka lang makadto. Pero subong may limit na nga amo na nga oras mapuli ka kay wala to sya upod. "(Time, because as a teenager I wanted to go somewhere. But since I have a child I could not get out, unlike before. Right now, there is a curfew because nobody is with her).

Aside from a lack of time with others, a lack of personal things is also experienced by the adolescent father. Bogie said, "sa mga balaklon maam, mga bayo tani nga daw iya ka soltero. Kay antes mo ibakal sang mga bayo na unahon mo anay pamilya mo. Gusto ko man tani mga bayo na maam. Galing kay gina kulang pa kamo nga daan sa balay, te unahon mo anay imo panimalay." (Things to be bought appropriate for a bachelor. Before you buy things for yourself you have to prioritize first your family. I should have wanted to buy my own clothes, but since my home is in need, I have to put them first).

Low life satisfaction and social exclusion are being confronted by the adolescent fathers (Sipsma, et al., 2010). Although there is a growing awareness to put in first their growing family's concerns, there is a risk that these adolescent fathers may experience the feeling of isolation from their social circle.

\section{Student Blues}

Being a student at the same time being an adolescent father is a source of concern for the participants. Leovy said, "Indi na ko ka tuon sang tsakto. Tapos kung may exam wala na time magtuon. Insigida nalang mag kuha exam. Gaka late pa ko kis-a." (I could not study well. During examinations I do not have time to study. Sometimes I come in late). Bogie also affirmed this concern, "sa pagtuon maam e, indi ka ka focus. Sa study indi ka ka focus. Kay ga problema ka pa sang galastuhon te indi ka ka focus sa study mo." (I could not focus in my education. I worry about finances therefore I could not concentrate).

Ken said, "sa pagpulaw bala haw. Te syempre sya bilog nga adlaw gabantay. Kapoy man sya kay wala man sang may gailis sa iya nga mabantay. Ma-kungkong tapos sa iya pa ga titi te mapulaw gid ko. Kis-a tuyo absent nalang. Kis-a gakaburawan. Mayo lang kung alas 9 ang klase kay makabugtaw alas 7. Kung MWF nga daan alas 7 ang klase te kisa gaabsent man e." (In sleeping late. She looks after the baby the whole day, and she is tired. She breastfeeds and take care of the baby, and so I take over at night. Sometimes I lack sleep so I become absent from school. Sometimes I wake up late, especially because my class during MWF [Monday, Wednesday and Friday schedules] is 7 o'clock so I become absent from my classes).

Bogie believes his lack of time for his family is also brought about by his school activities, as he said," ara bala maam nga indi ka kahatag time sa pamilya mo kay sako ka sa eskwelahan. Daku gid ang makuha nya nga time sa akon pamilya maam. Kay sa 1 ka adlaw nga daan maam ubos gid di ang time sa eskwelahan. Pagpuli mo lapyo ka na, indi ka na kaistorya-istorya. Matulog ka nalang." (I do not have time for my family because I am too busy with school activities. Everyday When I get home I am too tired, not even for a small chitchat. I just go to sleep).

Bibo said his being an adolescent father brings a lack of attention to his education, "kung gusto mo na gid bala nga mangita kwarta daw indi ka na mag eskwela daw wala ka na gana mag eskwela. Tapos kung may ubra ka maam daw kanami man sa pamatyagan nga maka ubra ka na kag may kwarta mabakal mo man sa eksakto..." (You have this desire to look for finances and you do not want to go to school anymore. It feels good to have a job since you have the money to buy things). Toby said the effects are, "sa allowance. Tunga na akon allowance kay na share ko sa bata. Sa pamensaron. Sa tulun-an kay syempre magtuon ka kabudlay nga may napamensar mo nga, ano naman ni dason man? Ano himuon ko? Wala ko kwarta. Ang problema man lang maam, ang budget maam mong. Kwarta. Kay kinanglanon mo gid na ya. Amo gid na ang realidad ya, kinanglanon mo gid ang kwarta. Kada giho mo nga daan subong kwarta nalang. Budget nalang. (My allowance is divided for I share it to my child. In my studies since I could not study well for I am thinking, What's next? What do I do? I don't have the money, for it is a need. It's the reality that in everything you do you need money).

Significantly associated with becoming a young father is low educational level (Colmar, et. al., 2009). $100 \%$ of the participants in this research have experienced problems regarding their education during their partners' pregnancy.

\section{The Ways of Coping Employed by the Adolescent Fathers}

The adolescent fathers' ways of coping could be divided into two (2) broad dimensions: avoidant/emotion-focused coping and proactive/problem-focused coping.

The Avoidant/Emotion-focused coping refers to the coping mechanisms employed by the adolescent fathers which focuses only on the emotions he experiences as he confronts the difficulties of early fatherhood. This kind of coping is also sometimes 
called avoidant coping because the individual does not confront the problems but creates an escape from the situation by avoiding the situation, fleeing from the situation to be free from the difficulties. Proactive/Problem-focused coping refers to the kind of coping employed wherein the person confronts the situation, and may think and propose ways of how he can face or overcome the problem.

\section{Avoidant/Emotion-Focused Coping (A child by heart)}

The Avoidant/Emotion-focused coping employed by the adolescent fathers all takes its toll in their education. Their education is the primary recepients of their negative emotions, for most of them experienced difficulty with their subjects during the time when their partners became pregnant. Nonoy stated, "Nagnubo lang maam mga grades ko." (My grades suffered). Bibo, on the other hand, said, "damo ka na absent. Gaka drop ka sa isa ka subject. Sang nagligad damo-damo gid maam dropped halos tanan. Daw indi nalang ko to gani mag eskwela maam kay daw tanan ko nga subject gaka pabay-an ko daw indi ko nalang pagsudlan. Kaagi ko to gani probationary status maam. 12 units akon fail kag drop." (I have too many absences and there was a time I was dropped from almost all my subjects. I lost interest in my studies. I went through becoming on probationary status, for I was dropped and failed in an accumulated 12 units). Bogie said, "Una indi ka ka contentrate sa pagtuon. Sang $2^{\text {nd }}$ year ko kay na failure ko to mong." (I could not concentrate in my studies, I failed in my subjects then). He added, "Kay sang amo to nga time maam ga exam indi ko kapamensar mayo kay ang napamensar ko ang asawa ko. Gabusong pa lang to sya maam mga 4 ka bulan. Wala pa to kami kapanugid." (I could not think clearly during that time for I was thinking of my partner. She was then four months pregnant. We were then not able to tell our parents). Leovy affirmed the same, as he said, "syempre maam sa pag eskwela mo, indi ka na mag tuon, ma nubo imo grades. Kung kis-a gaka late ko maam kung 730 klase ko. Indi na ko kaubra sang mga projects, mga assignments. Maka ubra ko tuod diri, pero late. Pagtapak pila ka bulan, mga 4 months pagbata nya, didto na ko gatulog sa ila, didto nagnubo akon nga grades." (Of course regarding my studies, I could not study well so my grades dropped. Sometimes I come in late. I did not have the time to do projects and assignments. Four months after when she gave birth, I stayed in their house, and that was when my grades dropped).

The myriad of concerns regarding obligations and responsibilities interfere in the ability of the adolescent father to focus in their education. Bogie said, "Tapos ga ano ka maam, ga problema ka sa ano mo maam, sa financial mo maam. Nga ga pamensar ka bala maam haw, "ano igasto ko sa iya?" tapos ga ano maam gaka apektuhan ang relasyon mo sang imo ginikanan, kay gapamensar ka kung paano ka kapangayo sa imo ginikanan kay ihatag mo sa iya. Tapos ano dayon maam, pinansyal man sa pag eskwela. Pinansyal gid ya maam. "(I am concerned with the finances. I was thinking of what to spend for her needs. My relationship with my parents was affected since I was concerned of how to ask money from them. Financial concerns for my studies. It's all about financial needs). JJ added, "kay pagkabalo ko na, nawad-an na ko gana mag eskwela. Kay hambal ko, kung mag eskwela pa ko, magastusan lang gasto pa nga daan sa bata, gasto na gid. Tapos masalig pa ko nga daan sa ginikanan ko sang ihatag sa bata ko, daw indi naman guro eksakto. Nag stop ko eskwela, mga 2 years guro. "(When I knew she was pregnant, I lost interest in my studies. If I continue, it would cost my parents too much since they still have to spend for the baby. It seems so much for them. I stopped going to school, it must have been for 2 years).

Leovy's regret for what happened to him was also apparent, as he said, "Kay kung wala ko naka pabusong tani okay pa tanan, wala sang may nag ilinaway, wala sang may nagbasulay. Tani subong okay pa kami sang pamilya ko. Subong maam ga lainay kami buot ni tatay, magpuli ko sa balay ga pawala sya." (Had I not made her pregnant, everything would have been okay, there would have been no quarrels, no blaming. My family and I would have been okay. Right now my father and I are not in good terms, he does not seem to notice me when I go home).

The adolescent fathers have experienced a lot of negative emotions regarding their situation. They resorted to blame, to regret, and most of them have lost interest in their studies. Attitude is an outlook in life- how a person responds to people and events (Masters and Wallace, 2010). Many of them exhibited negative attitudes to their problems.

Aside from these negative attitudes towards negative events, the adolescent fathers have manifested more of the positive attitude and decided to confront their problems level-headed. These positive responses are presented in the next dimension of their coping.

\section{Proactive/Problem-Focused Coping (l'd stand up like a man)}

This kind of coping shows the capacity of the adolescent father to think of solutions, to confront their challenges as fathers and offer possible resolve to give direction to their lives.

To confront their financial problem, the adolescent father employed proactive coping skills by thinking 
of ways, showing their maturity in handling their difficulties.

\section{Budgeting}

Toby, Leovy and Bogie decided to divide the allowance given to them by their parents into half, the other half for their needs and the other half they use for their children's needs. Toby said, "Te ginatagaan ya ko (mother) allowance wala na ko gapangayo para sa kinahanglanon sang bata. Wala na para sa bata maam amo na bahala kung paano ko tungaon. Example bi ang allowance ko, P150.00 ang adlaw. Tunga kami 75-75 kami. Pletehan ko pa na, back-and-forth 40, 30 nalang bilin sa akon. Akon nalang na diskarte kung paano ko mapa igo." (My mother gives me allowance and it does not include the budget for the baby. It is up for me to divide. For example my daily allowance is P150.00, I divide it between me and the baby, P75 for each of us. I spend for my fare, P40.00 and P30.00 is left for me. It's up to me to make ends meet.) Leovy said, "ang semana na bale 500 maam. Kung kis-a kung wala alamutan galab-ot P250.00 ang na save ko. Kung kis-a P300.00." (My weekly allowance is $\mathrm{P} 500.00$. Sometimes my savings reach to $\mathrm{P} 250.00$ or P300.00). Bogie said, "budget lang gid maam. Dapat sa sa ka adlaw maka gasto lang ko P10.00 or $\mathrm{P} 5.00$. kay ang akon allowance P300.00 sa isa ka semana. Te budget lang gid maam. Te kung may photocopy wala na ko ga photocopy gapang hulam lang ko. Kay ang kwarta gina tigana ko kay basi manamkon sya, te kinanglan kwarta." ( Budgeting. I need to spend only P10.00 or P5.00 each day since my allowance was only P300.00/week. I do not photocopy materials, I just borrow. She may need the money for her infanticipation). When asked what he could buy for 5 pesos, he replied, "bale sa sud-an na maam, ga amot amot kami sa boarding house. 4 kami maam, gabakal kami isda, gina prito namon kag gina tapahan isa na ka adlaw nga sud-an. " (For our viand, there are four of us in the boarding house who contribute together, and we buy fresh fish that we fry or grill and will last us for one day).

Bogie, Bibo, Jimmy and JJ decided to take matters into their own hands by finding means to support their babies and partners' needs. Bogie said, "sabado-dominggo gaubra gid ko maam ya. Para may kita man ko. Gahakot ko balas maam para ka kwarta kami ibakal sang amon kinahanglanon. Bale maam for example bi may truck nga gapakarga balas, kami na gakarga balas maam. Nasulod na sa sako sang semento ang balas, may ayagan man kami maam. Gina bayaran kami, by minetro maam. Depende kung pila ka trip ang amon bayad maam. Kay kaagi ko sang soltero pa ko maam, sa 1 ka semana ga dalagan 800.00 akon sweldo. Ina kung wala ga eskwela. Bilog nga adlaw na nga ubra maam. (Every weekend I haul sand for our needs.
When there are trucks who haul sands, we are the ones who load these, place them in sacks, and we are paid by the number of cubic meters. When I was still single, we are paid P800.00 weekly, we were then working the whole day). "Bibo said, "gapaninguha maam e. nga makakita man ubra. Gabubod ko bangrus. Ang akon bulan tag 3,500.00. wala labot may ara pa gid ko sideline. Kada aga sa merkado ga kargador ko maam." (I try hard to look for jobs. I feed bangus in fish pens, I am paid P3500.00 monthly. Aside from this, I also have a sideline job. Every morning I haul fish in the fish market). JJ said, "gasupport ko sang una, gahatag ko sa iya support napadal-an ko lang sya. Amo na ga byahe-byahe lang ko tricycle kis-a tapos ga sideline ko tainor sa banda. Kung may mga festival-festival, ga sideline-sideline ko. Amo lang na gahatag ko sa iya." (I was supporting her, I drive a tricycle and sometimes I train drum and bugle corps in schools. When there are (town) festivals, I have jobs and I give her what I earn). Jimmy said, "may ara ko maam small business. May tyangge ko sang una ma'am. Subong may isda ko, ornamental nga isda naman." (I have a small business, I had a mini grocery. Right now I sell ornamental fishes.)

Nonoy and Ken resolved that they could not do anything for now but to rely on the support of their parents, or to fate. Nonoy said, "nangayo man bulig sa kay tita ko maam e. Nangamuyo lang maam e nga mag ayo sya. Kag nangayo bulig sa iban. Sa tita ko maam. Naghatag man sya." (I asked help from my tita and from the others, and prayed that she (baby) would be okay.) Ken said, "syempre gasalig pa lang kay wala pa ubra. Te ga salig lang e sa ila ni papa. Bale kung magpadala sila dala na ang budget sa bata. Gina dugangan nila magpadala sa akon. Mapadala sila sa akon kay sang wala pa bata bala haw, isa ko ka bulan i ka libo. Subong ya kis-a duha ka libo." (I rely from my family. When they send me money, it already includes the budget for the baby. Previously they send me P1,000.00 now they send me P2,000.00).

Vickers (2010) in his study on adolescent pregnant students affirmed that the young woman is the expert of her own life and develops responses to fit her own needs. On the other hand, these adolescent males exert creativity to find resources for extending support to their family, by any means.

\section{Appease and Communicate}

The adolescent fathers decide that in order to cope with the existing difficulties, they could not do anything but to pacify their families by submission, and they could in a way do this by showing demeanors which would soothe them. Nonoy said, "Te na try ko gid ang best ko nga mag ayuhay tanan. Magpuli ko sa balay gabulig ko paninlo, gabulig ko sa balay. Sa ila balay, gina pareho ko 
man sa balay. Kung wala ko ubrahon ga panglimpyo man, ga panghugas pinggan. "(I try my best to soothe everybody. When I go home I help in the household chores. I do the same in their home).

Silence could also be interpreted as a way of appeasement, so as not to make things worse. Bibo said, "ginapabay-an ko man lang sila maam. Ginabalewala ko nalang bala haw. Kay kung sapakon mo malain man ang ila buot malain man ang akon buot. Napabay-an ko nalang. Gapabaya lang. Daw waay ka lang kabati bisan kabati ka daw wala lang gapabungol lang. Para indi lang mag lala." (I allow everything as it is. When I take notice we would all just be hurt. I do not just seem to hear so as not to make things worse).

Nonoy further affirmed that to appease his angered partner, "na angga angga ko lang sya maam e na explain ko sa iya nga friends lang kami, kag indi sya dapat magselos." (I soothe her and explain that they are all but just friends to me so that she would not be jealous).

Confrontation by communicating their thoughts is one coping skill manifested by the adolescent father. Bogie said about his siblings, "gapangayo man ko sa ila pasensya maam. Gina isipan man ko nila kung kis-a sa pagkaon maam mong. Dapat sa ila pa na makadto mong, subong gakadto na sa akon pamilya kay akon asawa ara man sa amon. Indi man ko gusto nga isaylo saylo sya sa mga tiya nya maam kay ano ang ihambal nila sa akon, nga ginpangasawa ko sya kag indi man ko kasarang." (I ask forgiveness from them. They notice our shortage of food, for what we consume was supposed to feed them. I do not want to send her to her aunties, for what would they say of me? I made her my wife yet I could not feed her). JJ said, "kung magkadto ko sa ila, tapos nag try ko mag communicate sang nag bata na sya, gin try ko mag communicate sa ila, sa nanay nya lang galing, gin explain ko man sa iya kung ano bala ang himuon ko. Kung ano ang plano ko, kung ano ang plano ko sa amon nga 2 bala." (I tried to communicate with her family when she gave birth. I explained to her mother my plans for us.)

On the other hand, Bibo communicated his thoughts to his partner, "gasabat man maam e kay kis-a daw indi mo man mapunggan mong. Te gasabat e. Ga langot man sa imo buot, hambalan ko sya, "te mayo tani kung wala ta nag updanay nga duha," ga amo man ko na. " (I answer back, and I tell her, ' We are better off not being together.') Ken, on the other hand, said, "kung maghapon nga mag abot na si ta nene (the partner's mother) ga lisensya ko nga ma gwa kag mag hampang hampang basketball sa gwa." (When Tita Nene arrives in the afternoon, I ask permission to get out to play basketball).

According to Jordan (2010), growth-fostering relationships were central to the rich stories of the participants and that the participants' well-being, growth and resilience were the benefits of significant relationships. Their family's support on either the financial or in the emotional level is central to the achievement of a well balanced life for the adolescent fathers.

\section{Acceptance}

The participants resolved that there is no way but to accept their present predicaments and condition. Bogie said, "nabaton ko nalang maam. Nabaton ko nalang maam kay sala ko gid man tuod mong. Kung wala lang ko tani nagpa dali dali, tani wala ko sa amo ni nga sitwasyon. (I accept everything Ma'am, for it was my fault. Had I not been in a hurry, I would not have been in this situation). JJ said regarding other people's opinions, "napabayan ko nalang tapos napanumdom ko, "akon man na ya. Wala man ko gapangayo sa ila. Kung gahatag gid man ko sa bata wala man ko gapangayo sa ila sang ihatag. Tapos akon man na ya. Tapos hambal ko, "indi ko na sila dapat sapakon, kay total indi man na ila." (I leave them alone and I think to myself, I do not ask from them. If I give support to my child, I do not ask money from them. I do not need to mind them, for this is my concern).

Regarding his difficulties with his subjects, Ken said, "wala e. pilit bugtaw e." (I try hard to wake up early.) Bogie further added, "ano maam, bisan tuyo tuyo na ko maam, ga basa gid ko maam. Basa gid maam ang importante kag pag intyende mong. Bisan nga gina kulang ko sa financial, indi mo man kinanglan talikdan ang pag eskwela mong. Matuon ka gid maam e. "(Though I am sleepy, I read because it is important along with understanding. Though I lack financially, I need not leave my studies for granted).

\section{Conclusion and Recommendations}

Two main themes emerge from the analysis of the adolescent fathers' challenges: the personal and the societal. The personal concerns of the adolescents involve their financial concerns, their own need for personal time and other worries and concerns regarding their education. The adolescent fathers' societal challenges involve their own family dynamics including their family's reaction to their early fatherhood, the new dynamics of their relationship with their partners and the fear that they would be judged by others. The adolescent fathers coped with these challenges in two ways: by avoidant/emotion-focused coping and by proactive/problem-focused coping. Avoidant/ emotion-focused coping refer to their emotional 
approach to the present problem. The proactive coping refers to their more matured handling of their challenges, which they did through budgeting, by appeasement and by communicating their thoughts and by acceptance of their present situation.

As a result of the findings of this study, the following recommendations are proposed:

1. The Guidance Office may conduct a program for the adolescent males to disseminate information regarding their reproductive capacities, especially at the delicate period of adolescence and serve a warning of the decisions which they may haphazardly do at this stage of development. This venue may also serve as a forum for informationdissemination of the challenges experienced by the adolescent fathers, to warn them of the possible circumstances associated with adolescent fatherhood..

2. The family members of the adolescent males, especially their parents, may be called for a forum to inform them of the challenges experienced by the adolescent fathers.

3. Other forms of proactive coping may be introduced to the adolescent males.

4. The information synthesized from this research may be disseminated to the community in the form of an outreach activity so as to gather also opinions and insights as to how the community members could help in the prevention of adolescent pregnancy and adolescent fatherhood.

\section{References}

1. Agarwal, Nidhi and Gupta, Jayanta Das, (2018). "School Effectiveness in The Development of High School Children". International Journal of Academic Research and Development, 3(4); 200-202; doi:10.5281/zenodo.3806990.

2. Agarwal, Nidhi, Kumar, Puneet and Mishra, Sugam, (2010). "Need to acquire democratic competency by Teacher Educator in global Scenario". Maa Omwati Journal of Education Research \& Development, 1(1); ISSN: 09761365, doi:10.5281/zenodo.3837657.

3. Bernal, C., (2013). Parenting Skills for Young Dads in Detention: Breaking the Cycle of Abuse and Neglect.

4. Colman I., Murray J., Abbott R.A., Maughan B., Kuh D., Croudace T.J., Jones P.B., (2009). Outcomes of conduct problems in adolescence: 40 year follow-up of national cohort. BMJ, 338.

5. Chin, R., Hall, P. and Daiches, A., (2011). Fathers' experiences of their transition to fatherhood: A Metasynthesis. Journal of Reproductive and Infant Psychology, 29(1).
6. Corpuz, B., Lucas, M.R., Borabo, H.G. and Lucido, P., (2010). Child and Adolescent Development. Quezon City: Lorimar Publishing, Inc.

7. Creswell, J., (2009). Research Design: Qualitative, Quantitative and Mixed Method Approaches, $3^{\text {rd }}$ ed. Los Angeles: Sage Publications, Inc.

8. Goel, Ankit and Agarwal, Ekansh, (2019). Assessing Innovation in Teacher Education. Globus Journal of Progressive Education, 9(2); 50-52, ISSN: 2231-1335.

9. Havighurst, R., (1972). Developmental Tasks and Education, $3^{\text {rd }}$ ed. N.Y.: Longman.

10. Hofferth, S. and Goldschneider, F., (2010). Family Structure and the Transition to Early Parenthood. Demography, 47 (2); 415-437.

11. Jordan, J.V., (2010). Relational-Cultural Theory. Washington, D.C.: American Psychological Association.

12. Lee, C., Sansone, F.A., Swanson, C. and Tatum, K.M., (2012). Incarcerated fathers and parenting: Importance of the relationship with their children. Social Work in Public Health, 27; 165-186.

13. Lehti, V., Sourander, A., Sillanmaki, L., Helenius, H., Tamminen, T., Kumpulainen, K., and Almqvist, F., (2012). Psychosocial Factors Associated with Becoming a Young Father in Finland: A Nationwide Longitudinal Study. BMC Public Health, 560 (12).

14. Lucas, M. and Corpuz, B., (2013). Facilitating Learning: A Metacognitive Process, $3^{\text {rd }}$ ed. Metro Manila, Philippines: Lorimar Publishing, Inc.

15. Luz A.M. and Berni N.I., (2010). Paternity Process in The Adolescence. Brazilian Journal of Nursing, 63(1).

16. Masters, L. and Wallace, H., (2011). Personal Development for Work and Life. Pasig City, Philippines: Cengage Learning Asia Pte Ltd.

17. McBride, D., (2013). "Uplifting the Family: African-American Parents' Ideas of how to Integrate Religion Into Family Health Programming". Journal of Child and Family Studies, 22(1); 16-28.

18. Molborn, S. and Lovegrove, P.J. (2011). How Teenage Fathers Matter for Children: Evidence From ECIS-B. Journal of Family Issues, 32 (1); 3-30.

19. Parungao, C., Bautista, L., Mariano, R., Bonifacio, V. and Aguinaldo, M., (2014). Life Brought at a Tender Age: The Lived Experiences of Filipino Teenage Pregnant Women. Asia Pacific Journal of Multidisciplinary Research 2(1). Retrieved fromhttp://staff.uny.ac.id/sites/default/files/pen elitian/aprilia-tina-lidyasari-mpd/b6-jurnalinternasional-apjmr.pdfretrieved on 8-11-15. 
20. Paschal, A.M., Lewis-Mors, R.K. and Hsiao, T., (2011). Perceived fatherhood roles and parenting behaviors among African-American Teen Fathers. Journal of Adolescent Research. 26 (1); 61-83.

21. Rice, F.P., (2010). Human Development: A Life-Span Approach. Pearson Learning Solutions, United States of America.

22. Senn, T.E. and Carey, M.P., (2011). Age of Partner at first Adolescent Intercourse and Adult Sexual Risk Behavior Among Women. Journal of Women's Health, 20 (1); 61-66.

23. Sipsma, H., Biello, R.B., Cole-Lewis, H. And Kershaw, T., (2010). Like father, Like Son: The Intergenerational Cycle of Adolescent Fatherhood. AM. Journal of Public Health, 100 (1); 517-524.
24. Vashishtha, Sangeet and Sharma, Pooja, (2018). Big Data- New Trend of Change in Complex Corporate World. Globus An International Journal of Management \& IT, 10(1); 4-6, ISSN: 0975-721X.

25. Vickers, M., (2010). Personal Narrative: The Struggles of Teenage Pregnancy Through a Teenager's Eyes with an Adult Perspective. Retrieved from http://pqdtopen.proquest.com/doc/756234862. html?FMT=AI Retrieved on 9-2-15.

26. Weinman, M., Small, E., Buzi, R. and Smith, P., (2008). Risk Factors, Parental Communication, Self and Peers Beliefs and Predictors of Condom Use among Female Adolescents Attending Family Planning Clinics. California Social Work Journal, 25(3); 157-176. 